\title{
Multiple metasomatic events recorded in MARID xenoliths
}

\author{
Angus Fitzpayne ${ }^{1}{ }^{*}$, Andrea Giuliani ${ }^{1,2}$, David Phillips ${ }^{1}$, Janet Hergt ${ }^{1}$, James Farquhar ${ }^{3}$, \\ Russell N. Drysdale ${ }^{4}$ \\ ${ }^{1}$ KiDs (Kimberlites and Diamonds), School of Earth Sciences, The University of Melbourne, Parkville, 3010 \\ Victoria, Australia (*afitzpayne@student.unimelb.edu.au) \\ ${ }^{2}$ ARC Centre of Excellence for Core to Crust Fluid Systems and GEMOC, Department of Earth and Planetary \\ Sciences, Macquarie University, North Ryde, 2019 New South Wales, Australia \\ ${ }^{3}$ Department of Geology and ESSIC, University of Maryland, College Park, Maryland 20742, USA \\ ${ }^{4}$ School of Geography, The University of Melbourne, Parkville, 3010 Victoria, Australia
}

\section{Introduction}

MARID (Mica-Amphibole-Rutile-Ilmenite-Diopside) and PIC (Phlogopite-Ilmenite-Clinopyroxene) xenoliths are interpreted as extremely metasomatised mantle rocks, based on their high abundances of alkali metals and volatile components. MARID xenoliths are often traversed by compositionally distinct carbonate- and serpentine-rich veins, and exhibit other signs of metasomatic overprinting (e.g., chemical zonation of the main mineral constituents). To characterise the compositions and origins of metasomatic fluids that have overprinted MARID and PIC xenoliths, we have examined the petrography and mineral chemistry of vein assemblages and the compositional zoning of MARID-PIC phases in 28 xenoliths from southern African kimberlites and orangeites from the Kimberley and Barkly West areas. For one sample, detailed C-O-S-Sr isotopic work on clinopyroxene, calcite, sulfides and sulfates in carbonate-rich veins was undertaken in order to clarify the origin(s) of the metasomatic fluid.

\section{Petrography}

Carbonate- and serpentine-rich veins in MARID rocks contain small $(<100 \mu \mathrm{m})$, euhedral grains of clinopyroxene, phlogopite and ilmenite, as well as minerals (e.g., apatite, $\mathrm{Cr}$-spinel) that are not associated with the primary MARID paragenesis (Fig. 1a). Primary MARID phases are often zoned when in contact with these veins. Similar veins are not observed in PIC rocks, which instead display rare serpentine pools containing small $(<50 \mu \mathrm{m})$ grains of magnetite, as well as less common ilmenite, rutile, titanite and Cr-spinel. "Spongy" rims surrounding both MARID and PIC clinopyroxene grains (Fig. 1b) display a mineral inclusion assemblage similar to the groundmass mineralogy of kimberlites.
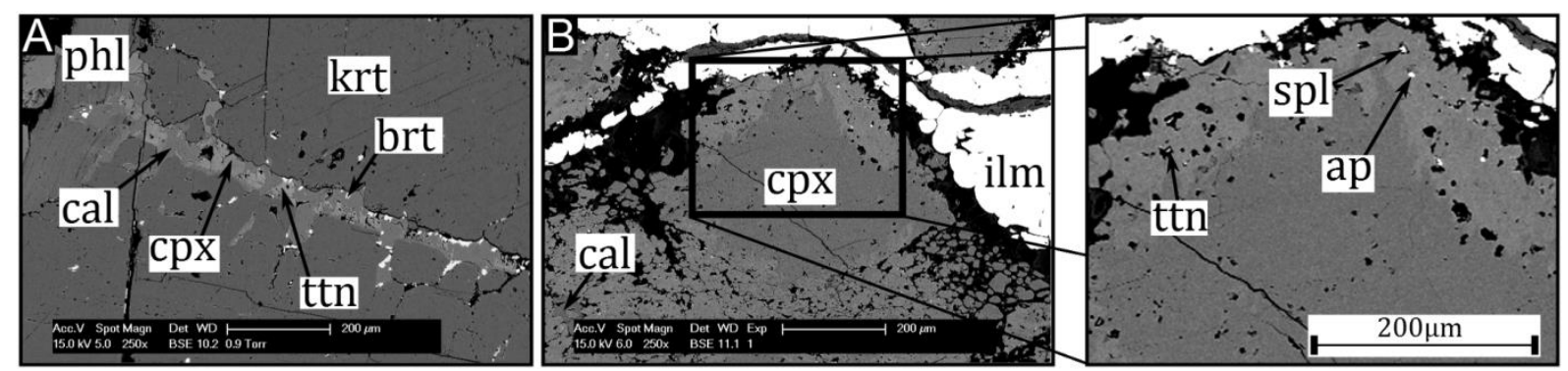

Figure 1: SEM back-scattered electron images of: A) calcite (cal) vein, containing "secondary" (i.e. nonMARID) clinopyroxene (cpx), titanite (ttn), and barite (brt), traversing matrix phlogopite (phl) and K-richterite (krt) in MARID sample BLFX26; B) zoned cpx, adjacent to ilmenite (ilm) in PIC sample AJE540, while patchy cc occurs between small cpx; cpx rim contains inclusions (inset) of ttn, apatite (ap), and spinel (spl).

\section{Mineral chemistry}

"Secondary" (i.e. non-MARID) clinopyroxene grains display higher $\mathrm{TiO}_{2}$ contents than "primary" MARID grains $(0.8 \pm 0.5 \mathrm{wt} \%$ and $0.10 \pm 0.05 \mathrm{wt} \%$ respectively). "Spongy" clinopyroxene rims in MARID and PIC rocks also exhibit $\mathrm{CaO}$ enrichment and $\mathrm{Al}_{2} \mathrm{O}_{3}-\mathrm{Na}_{2} \mathrm{O}$ depletions relative to their 
cores. "Secondary" clinopyroxene grains in MARID rocks exhibit distinct trace element patterns, resembling either primary MARID or PIC clinopyroxene (Fig. 2a, b). Clinopyroxene spongy rims are REE-depleted relative to their cores in MARID samples, whereas those in PIC rocks are relatively REE-enriched (Fig 2c, d). "Secondary" phlogopite grains also have higher $\mathrm{TiO}_{2}$ contents with respect to "primary" MARID grains ( $2.9 \pm 1.3 \mathrm{wt} \%$ and $1.4 \pm 0.9 \mathrm{wt} \%$, respectively). Two types of ilmenite occur in MARID xenoliths: "primary MARID" ilmenite in textural equilibrium with other MARID phases $\left(36.0 \mathrm{wt} \% \mathrm{FeO}_{\mathrm{T}}, 9.1 \mathrm{wt} \% \mathrm{MgO}, 51.7 \mathrm{wt} \% \mathrm{TiO}_{2}\right)$, and "PIC-like" ilmenite $\left(27.0 \mathrm{wt} \% \mathrm{FeO}_{\mathrm{T}}\right.$, $14.1 \mathrm{wt} \% \mathrm{MgO}, 55.8 \mathrm{wt} \% \mathrm{TiO}_{2}$ ), which occurs in veins or as thin rims around rutile grains.
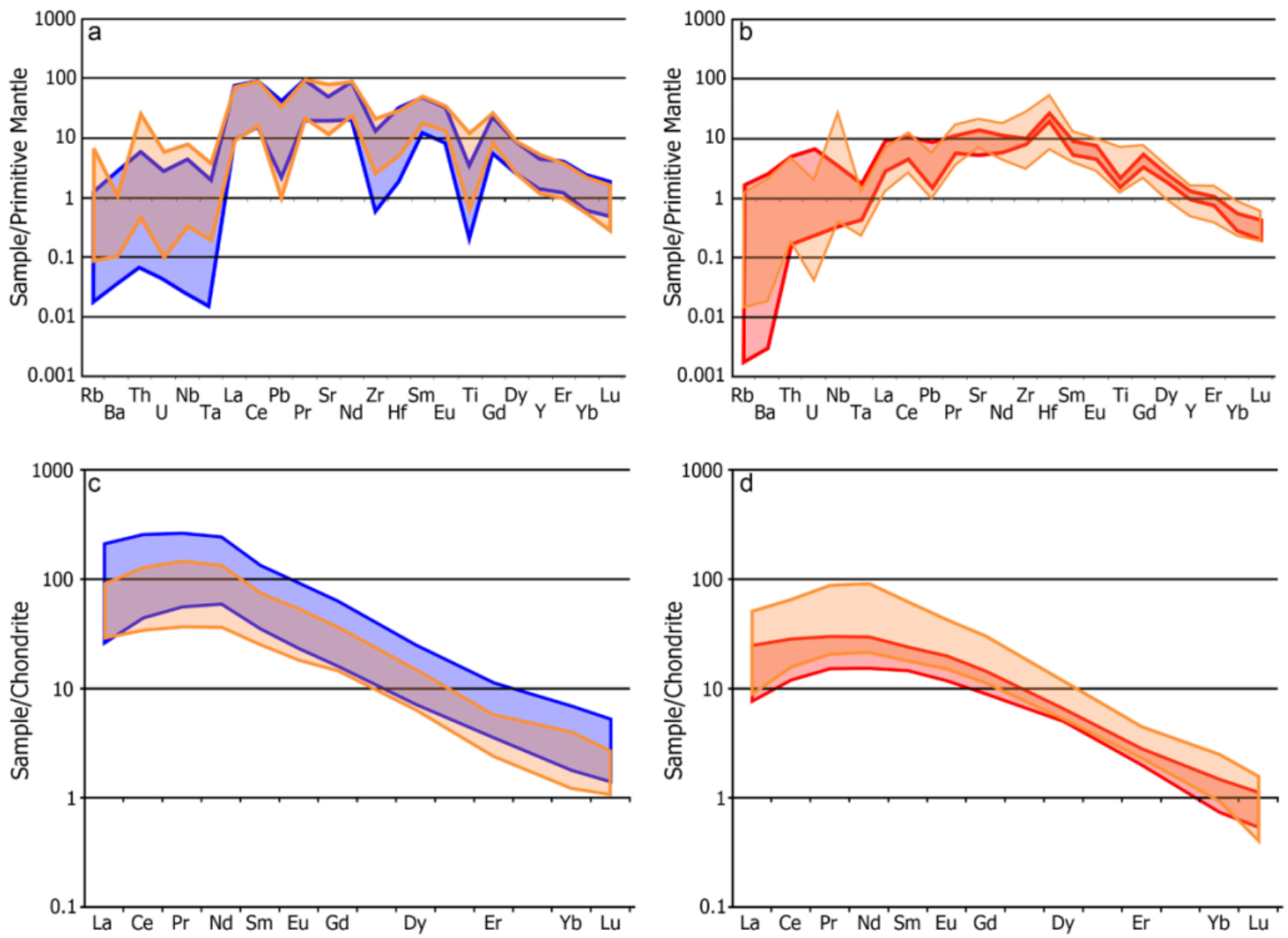

Figure 2: a,b) Primitive mantle-normalised trace element diagram showing MARID (blue field) and PIC primary clinopyroxene (red field) ranges from this study, relative to MARID- and PIC-like secondary clinopyroxenes in MARID rocks (orange fields); c,d) CI-chondrite normalised REE diagram for MARID (blue field) and PIC (red field) primary clinopyroxene ranges from this study, compared to spongy clinopyroxene rims around MARID and PIC clinopyroxene in this study (orange); all normalising values from McDonough and Sun (1995).

\section{Radiogenic Isotopes}

Sample XM1-331, derived from the Bultfontein kimberlite, hosts abundant carbonate-rich veins containing euhedral clinopyroxene and phlogopite, and lesser barite and sulfides. Strontium isotope compositions were collected in situ by LA-MC-ICPMS for primary clinopyroxene, K-richterite and phlogopite, and secondary clinopyroxene and carbonates. Primary MARID phases are in isotopic equilibrium with one another, but their isotopic compositions (i.e. primary clinopyroxene ${ }^{87} \mathrm{Sr}^{86} \mathrm{Sr}_{\mathrm{i}}=$ 0.70811 ) differ from those of the vein phases (i.e. vein clinopyroxene ${ }^{87} \mathrm{Sr}^{86} \mathrm{Sr}_{\mathrm{i}}=0.70581$ ).

\section{Stable Isotopes}

Oxygen isotope compositions of secondary carbonates from MARID sample XM1-331 are higher, and carbon isotope compositions are lower, compared with bulk carbonates in the kimberlite host 
$\left(\delta^{18} \mathrm{O}_{\mathrm{VSMOW}}=+17.22 \%\right.$ and $+11.73 \%$, respectively; $\delta^{13} \mathrm{C}_{\mathrm{VPDB}}=-9.18 \%$ and $-4.28 \%$, respectively $)$. Sulfur isotope analyses of bulk rock sulfide and a barite separate from sample XM1-331 provide $\delta^{34} \mathrm{~S}$ values $=-0.81 \%$ and $+4.69 \%$, respectively.

\section{Discussion}

No MARID phases occur as secondary minerals in PIC xenoliths, whereas some PIC-like clinopyroxene and ilmenite occur in veins in MARID samples, indicating that PIC mineral precipitation in the Kimberley area likely post-dated MARID formation. Some phases, such as clinopyroxene, in veins transecting MARID rocks display discrete compositional zones on a micron scale; such subtle zoning can only be preserved under mantle conditions for up to a few ky. The preservation of geochemical heterogeneities (as mineral zonation, as well as primary vs vein mineral compositions), in addition to $\mathrm{Sr}$ isotope disequilibrium between MARID and vein minerals in sample XM1/331, suggest that metasomatism occurred shortly before entrainment and transport to surface by kimberlite magmas.

The ${ }^{87} \mathrm{Sr} /{ }^{86} \mathrm{Sr}_{\mathrm{i}}$ of primary and secondary generations of MARID minerals indicate that, although MARID rocks may be generated from an enriched mantle source, subsequent phases of metasomatism are caused by mantle fluids with less radiogenic Sr. Coupled C-O isotope compositions suggest that vein carbonates could be sourced from mantle that has been enriched with recycled crustal material. Assuming sulfur isotopic equilibrium, barite and sulfides in MARID veins crystallised at $850-900^{\circ} \mathrm{C}$ (Miyoshi et al., 1984), consistent with the thermal regime of MARID formation (based on Ca-in-opx thermometry from Konzett et al., 2014). It can therefore be concluded that sulfur-rich fluids interacted with MARIDs during their residence in the lithospheric mantle, and not during transport to, or emplacement into, the crust.

While it appears that secondary metasomatic features in MARID rocks may be temporally linked to kimberlite magmatism, the C-O-S-Sr isotopic composition of vein material in sample $\mathrm{XM} 1 / 331$ is clearly unlike the host kimberlite. Therefore, we favour fluid derivation from a mantle source containing recyled material, the remobilisation of which was triggered by the thermal anomaly associated with kimberlite magmatism.

\section{References}

Konzett, J., Krenn, K., Rubatto, D., Hauzenberger, C., \& Stalder, R. (2014). The formation of saline mantle fluids by open-system crystallization of hydrous silicate-rich vein assemblages - Evidence from fluid inclusions and their host phases in MARID xenoliths from the central Kaapvaal Craton, South Africa. Geochimica et Cosmochimica Acta, 147, 1-25.

McDonough, W. F., Sun, S-s. (1995). The composition of the Earth. Chemical Geology, 120, $223-$ 253.

Miyoshi, T., Sakai, H., \& Chiba, H. (1984). Experimental study of sulfur isotope fractionation factors between sulfate and sulfide in high temperature melts. Geochemical Journal, 18(2), 75-84. 